\title{
Peran Media Roda Putar dalam Meningkatkan Efektivitas dan Efisiensi Penilaian Status Gizi Balita Oleh Ibu Balita Dan Bidan
}

\section{The Role of Turning Wheel Media in Increasing the Effectiveness and Efficiency of Toddler Nutrition Status Assessments by Toddler Mothers and Midwives}

\author{
Nurika Rahma1, Kusnandi Rusmil², Henni Djuhaeni ${ }^{3}$ \\ 1. Dosen Sekolah Tinggi Ilmu Kesehatan Budi Kemuliaaan \\ 2. Dosen Fakultas Kedokteran Universitas Padjadjaran Departemen Ilmu Kesehatan Anak \\ 3. Dosen Fakultas Kedokteran Universitas Padjadjaran Departemen Ilmu Kesehatan Masyarakat \\ email:aummiarthaf@gmail.com_bkusnandi@hotmail.com_chennidjuhaeni@yahoo.com
}

\begin{tabular}{l}
\hline I N F O A R T I K E L \\
\hline Sejarah artikel: \\
Menerima2 September 2019 \\
Revisi 25 September 2019 \\
Diterima 02 Oktober 2019 \\
Online 10 Oktober 2019 \\
\hline
\end{tabular}

Kata kunci:

Media roda putar, penilaian status gizi, status gizi balita

Keywords:[

Nutritional status

assessment, nutritional

status of children, rotary

wheel media

\section{ABSTRAK}

Dalam menilai status gizi balita, saat ini para tenaga kesehatan dan ibu balita menggunakan KMS, sayangnya alat tersebut tidak dapat mendeteksi kejadian balita pendek, karena tidak dilengkap indeks TB/U. Untuk melengkapinya, kalangan akademisi mengeluarkan software computer WHO anthro 2005, yang dapat mendeteksi seluruh masalah gizi, namun penggunaanya harus ditunjang dengan media elektronik yang dihubungkan jaringan internet, sehingga relatif sulit diakses masyarakat. Pemerintah mengeluarkan buku Kepmenkes 2010 tentang penilaian status gizi balita berdasarkan antropometri, akan tetapi buku tersebut hanya dapat dipakai oleh tenaga kesehatan. Melihat kondisi tersebut, maka diperlukan suatu media yang dapat menilai status gizi balita berdasarkan berbagai indikator secara efektif dan efisien, mudah digunakan oleh tenaga kesehatan maupun masyarakat umum.

Telah dilakukan dua siklus penelitian dengan metode kuasi eksperimen, pada siklus I membandingkan efektivitas dan efisiensi penggunaan media rotar dengan buku yang dilakukan oleh bidan puskesmas dengan jumlah sampel 18 subjek. Siklus II yaitu mengetahui efektivitas dan efisiensi penggunaan media rotar yang dilakukan oleh ibu balita dan Bidan Praktik Mandiri (BPM) dengan masing-masing jumlah sampel 30 subjek. Efektivitas yang dimaksud adalah tuntas dalam menilai diagnosa, skor ketepatan hasil $\geq 80 \%$ dan skor respon angket $\geq 70 \%$.

Hasil penelitian menunjukkan bahwa pada siklus I, efektivitas penggunaan rotar adalah tuntas, 96,28\% dan 93,33\% (sangat positif), sedangkan hasil dari penggunaan buku adalah tuntas, $85,17 \%$ dan $67,96 \%$ (kurang positif). Untuk efisiensi, rata-rata waktu penggunaan media rotar dan buku berturut-turut adalah 33 detik dan 102 detik. Pada hasil penelitian siklus II, efektivitas penggunaan rotar oleh ibu balita adalah tuntas, 95,55\% dan 89,33\% (sangat positif), sedangkan bidan adalah tuntas, 97,77\% dan t 92,67\% (sangat positif). Untuk efisiensi penggunaan media rotar oleh ibu balita dan BPM berturut-turut adalah 33 detik dan 27 detik.

Simpulan dari penelitian ini adalah penggunaan media rotar lebih efektif dan efisien dibandingkan dengan media buku dan penggunaan media rotar efektif dan efisien terhadap penilaian status gizi balita oleh ibu balita dan BPM. 


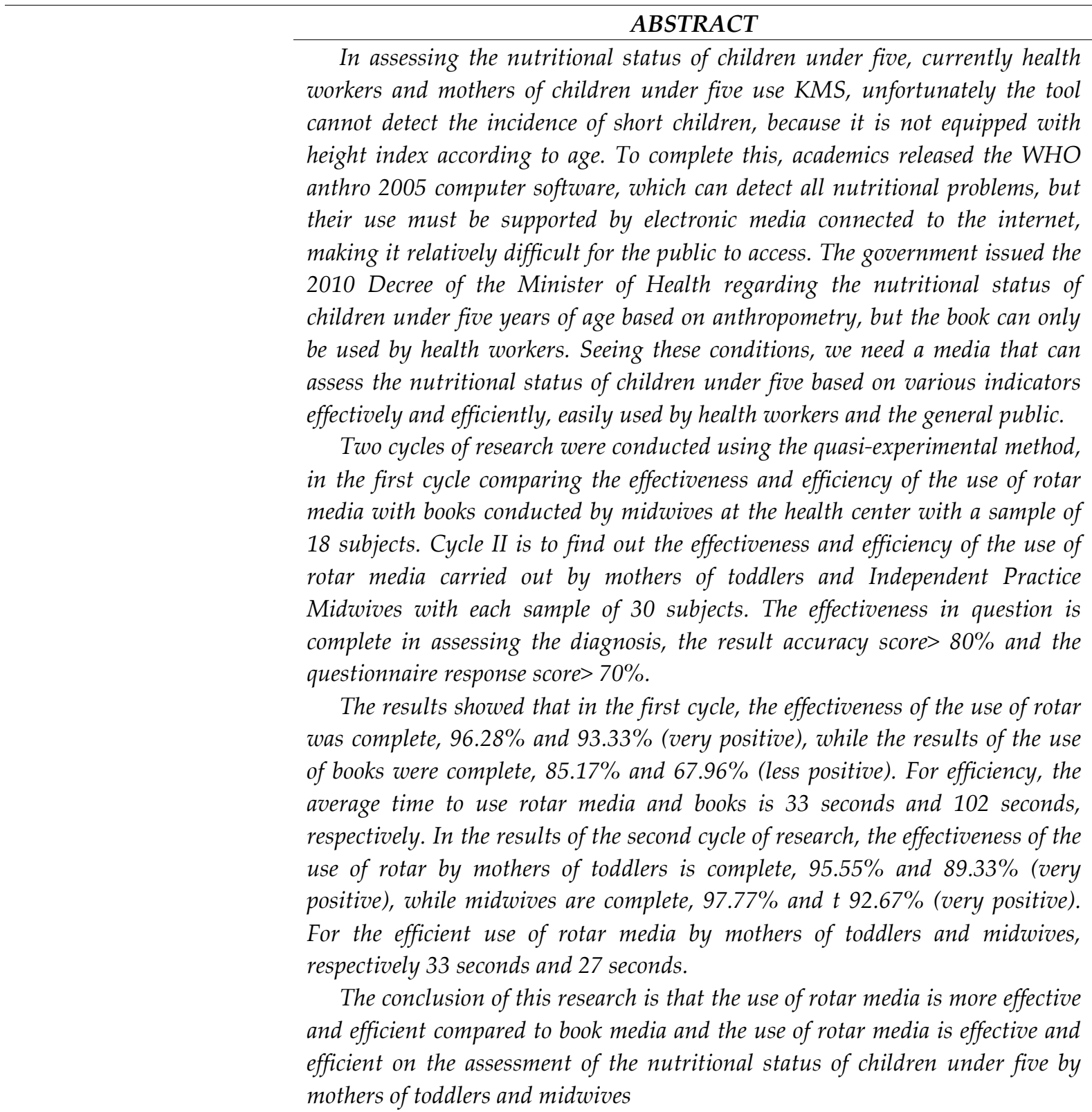

\section{PENDAHULUAN}

Keadaan gizi yang baik merupakan prasyarat terciptanya sumber daya manusia dengan masa depan yang berkualitas. Anak yang mengalami masalah gizi pada usia dini akan mengalami gangguan tumbuh kembang dan meningkatkan kesakitan, penurunan produktivitas serta kematian. Keadaan status gizi pada awal usia anak-anak merupakan salah satu kondisi gizi utama yang berkaitan dengan perkembangan anak, kemampuan kognitif dan afektif orang dewasa. Kekurangan gizi pada awal kehidupan anak akan berdampak pada kualitas sumber daya manusia. Anak yang kurang gizi akan tumbuh lebih pendek (stunting) dan berpengaruh terhadap perkembangan kognitif anak yang juga berpengaruh pada keberhasilan pendidikan.

Kekurangan gizi pada awal kehidupan anak akan berdampak pada kualitas sumber daya manusia. Hasil Riskesdas 2013, prevalensi balita pendek sebesar $37,2 \%$, balita kurus $12,1 \%$, gizi kurang 19,6\% dan gizi lebih 26,6\%. Saat ini, penilaian status gizi balita menggunakan KMS, sayangnya alat tersebut tidak dapat mendeteksi kejadian balita pendek, karena tidak dilengkapi indeks TB/U. Untuk melengkapinya, kalangan 
akademisi mengeluarkan software computer WHO anthro 2005, yang dapat mendeteksi seluruh masalah gizi, namun pada penggunaanya harus ditunjang dengan media elektronik yang dihubungkan jaringan internet, sehingga pada penggunaannya relatif sulit diakses oleh masyarakat. Pemerintah mengeluarkan buku Kepmenkes 2010 tentang penilaian status gizi balita berdasarkan antropometri dengan berbagai indeks, akan tetapi buku tersebut hanya dapat dipakai oleh tenaga kesehatan. Melihat kondisi tersebut, maka diperlukan suatu media yang dapat menilai status gizi balita berdasarkan berbagai indikator secara efektif dan efisien, mudah digunakan oleh tenaga kesehatan maupun masyarakat umum.

\section{METODE PENELITIAN}

Penelitian ini dibagi menjadi dua siklus. Siklus I, yaitu membandingkan efektivitas dan efisiensi penggunaan media roda putar dengan media buku yang dilakukan oleh bidan puskesmas dalam menentukan status gizi balita dengan menggunakan metode kuantitatif dengan desain kuasi eksperimen yang dilakukan pada tanggal 18-27 November 2015. Siklus II, yaitu mengetahui efektivitas dan efisiensi penggunaan media roda putar dalam menentukan status gizi balita yang dilakukan Tabel 1. Karakteristik Responden Pada Siklus I dan Siklus II

\begin{tabular}{|c|c|c|c|}
\hline \multicolumn{2}{|c|}{$\begin{array}{l}\text { Karakteristik } \\
\text { Siklus I }\end{array}$} & \multirow[t]{2}{*}{$\mathrm{n}=\mathbf{1 8}$} & \multirow[t]{2}{*}{$\%$} \\
\hline Bidan & Usia (tahun) & & \\
\hline \multirow[t]{9}{*}{ Puskesmas } & $20-35$ & 17 & 94,4 \\
\hline & $>35$ & 1 & 5,6 \\
\hline & Lama Bekerja & & \\
\hline & Baru & 5 & 27,8 \\
\hline & Lama & 13 & 72,2 \\
\hline & Keikutserrtaan & & \\
\hline & Pelatihan & 2 & 11,1 \\
\hline & Ya & 16 & 88,9 \\
\hline & Tidak & 10 & 00,7 \\
\hline \multicolumn{2}{|c|}{ Karakteristik Responden Siklus II } & $n=30$ & $\%$ \\
\hline \multirow[t]{3}{*}{ Ibu Balita } & Usia (tahun) & & \\
\hline & $20-35$ & 26 & 86,7 \\
\hline & $>35$ & & \\
\hline
\end{tabular}

oleh ibu balita dan Bidan Praktik Mandiri (BPM) pada tanggal 15-23 Februari 2016. Variabel dalam penelitian ini adalah media status gizi balita, efektivitas dan efisiensi. Instrument dalam penelitian ini menggunakan kuesioner. Data dikumpulkan secara deskriptif dan diuji statistic dengan analisis uji komparatif, yaitu uji wilcoxon.

\section{DISKUSI}

Hasil penelitian ini terbagi dalam dua siklus, siklus I bertujuan untuk membandingkan efektivitas dan efisiensi antara penggunaan media roda putar dan media buku. Siklus II bertujuan untuk mengetahui efektivitas dan efisiensi penggunaan media rotar terhadap penilaian status gizi balita oleh ibu balita dan bidan praktik mandiri serta mengetahui hubungan karakteristik pengguna terhadap efektivitas dan efisiensi media rotar.

\section{a. Karakteristik subjek penelitian}

Penelitian ini dilakukan terhadap 18 subjek bidan puskesmas pada siklus I dan pada siklus II sebanyak 30 subjek ibu balita dan 30 subjek bidan praktik mandiri (BPM). Karakteristik subjek dalam penelititan ini yaitu, pada ibu balita meliputi usia dan tingkat pendidikan formal, sedangkan pada bidan meliputi usia, lama bekerja dan keikutsertaan pelatihan yang disajikan dalam tabel 1.

$4 \quad 13,3$

\begin{tabular}{lccc}
\cline { 2 - 3 } & Tingkat Pendidikan & & \\
& Rendah & 5 & 16,7 \\
& Menengah & 15 & 50,0 \\
Tinggi & 10 & 33,3 \\
\hline Bidan & Usia (tahun) & & \\
& $20-35$ & 26 & 86,7 \\
& $>35$ & 4 & 13,3 \\
\hline & Lama Bekerja & & \\
Baru & 16 & 53,3 \\
& Lama & 14 & 46,7 \\
\hline & Keikutsertaan & & \\
Pelatihan & 8 & 26,7 \\
Ya & 22 & 73,3 \\
Tidak & &
\end{tabular}

Jurnal KebidananVol.8 No. 2 Oktober 2019 | 96 
b. Perbandingan Efektivitas dan Efisiensi Antara Penggunaan Media Roda Putar Dan Media Buku Dalam Menilai Status Gizi Balita.

Media dikatakan efektif jika memenuhi indikator rata-rata hasil penggunaan media adalah tuntas dan hasilnya lebih besar atau sama dengan $80 \%$ serta adanya respon positif dari para pengguna (responden) melalui angket, yaitu sama dengan atau lebih besar $70 \%$. Untuk efisiensi penggunaan media rotar dibagi dalam 2 kategori, cepat jika $\leq 33$ detik dan lama $>33$ detik, untuk penggunaan media buku dikatakan cepat jika $\leq 102$ detik dan lama $>102$. Hasil penelitian menyatakan bahwa seluruh responden tuntas dalam menggunakan media roda putar maupun buku dalam menilai status gizi balita, berikut adalah hasil analisis penelitian siklus I dapat dilihat pada tabel 2 dan tabel 3 .

Tabel 2. Hasil Analisis Perbandingan Efektivitas Penggunaan Media Roda Putar Dan Media Buku Dalam Menilai Status Gizi Balita.

\begin{tabular}{|c|c|c|c|c|}
\hline \multirow{3}{*}{$\mathbf{n}$} & \multicolumn{4}{|c|}{ Efektivitas } \\
\hline & \multicolumn{2}{|c|}{ Perlakuan } & \multicolumn{2}{|c|}{ Kontrol } \\
\hline & Skor & Respon & Skor & Respon \\
\hline 1 & 66.6 & 96.67 & 66.6 & 56.67 \\
\hline 2 & 100 & 100.00 & 100 & 76.67 \\
\hline 3 & 100 & 93.33 & 100 & 73.33 \\
\hline 4 & 100 & 93.33 & 100 & 66.67 \\
\hline 5 & 100 & 93.33 & 100 & 76.67 \\
\hline 6 & 100 & 93.33 & 100 & 76.67 \\
\hline 7 & 100 & 96.67 & 100 & 76.67 \\
\hline 8 & 100 & 93.33 & 100 & 66.67 \\
\hline 9 & 100 & 93.33 & 100 & 66.67 \\
\hline 10 & 100 & 96.67 & 100 & 66.67 \\
\hline 11 & 66.6 & 90.00 & 33.3 & 36.66 \\
\hline 12 & 100 & 80.00 & 66.6 & 43.33 \\
\hline 13 & 100 & 100.00 & 100 & 76.67 \\
\hline 14 & 100 & 83.33 & 66.6 & 46.66 \\
\hline 15 & 100 & 96.67 & 100 & 93.33 \\
\hline 16 & 100 & 90.00 & 100 & 76.67 \\
\hline 17 & 100 & 100.00 & 66,6 & 53.33 \\
\hline \multirow[t]{2}{*}{18} & 100 & 90.00 & 100 & 93.33 \\
\hline & 96,28 & 93,33 & 85,17 & 67,96 \\
\hline
\end{tabular}

Tabel 2 menunjukkan hasil efektivitas penggunaan media roda putar lebih efektif dibanding media buku dalam menilai status gizi balita.
Tabel 3. Hasil Analisis Perbandingan Efisiensi Media Roda Putar Dan Buku

\begin{tabular}{lc} 
Kecepatan waktu Bidan Puskesmas & $\begin{array}{c}\text { Median } \\
\text { (Min-Maks) }\end{array}$ \\
\hline Media Rotar & $32,5(18-69)$ \\
\hline Media Buku & $102(54-199)$ \\
\hline Nilai $\mathrm{p}^{*}=0,001$ (Uji Wilcoxon) \\
18 subjek lebih cepat menggunakan media rotar
\end{tabular}

Keterangan : *) Uji Wilcoxon digunakan untuk uji komparatif dengan skala numerik distribusi tidak normal, dua kelompok berpasangan.

Tabel 3 menunjukkan efisiensi waktu penggunaan media roda putar lebih efisien dibanding media buku dalam menilai status gizi balita.

\section{c. Efektivitas dan Efisiensi Penggunaan Media Roda Putar Dalam Menilai Status Gizi Balita.}

Pada penelitian siklus II ini akan dipaparkan tentang efektivitas dan efisiensi penggunaan media roda putar dalam menentukan status gizi balita yang dilakukan oleh ibu balita (n1) dan bidan praktik mandiri (n2) Indikator efektivitas pada siklus II ini sama seperti siklus I. Untuk indikator efisiensi di siklus II, dibagi dalam 2 kategori, cepat jika $\leq 31$ detik dan lama jika $>31$ detik untuk ibu balita, dan untuk bidan dikatakan cepat jika $\leq 24$ detik dan lama jika $>24$ detik. Berikut adalah hasil analisis data efektivitas dan efisiensi waktu penggunaan media rotar yang disajikan dalam tabel 4.

Tabel 4. Efektivitas dan Efisiensi Penggunaan Media Roda Putar Dalam Menilai Status Gizi Balita.

\begin{tabular}{cccc} 
& \multicolumn{2}{c}{ Efektivitas } & Efisiensi \\
\cline { 2 - 3 } $\mathbf{n} 1$ & Skor & $\begin{array}{c}\text { Respon } \\
\text { Angket }\end{array}$ & \\
\hline 1 & 100 & 93.33 & 38 \\
\hline 2 & 100 & 93.33 & 44 \\
\hline 3 & 100 & 90.00 & 31 \\
\hline 4 & 100 & 90.00 & 27 \\
\hline 5 & 100 & 90.00 & 60 \\
\hline 6 & 100 & 90.00 & 29 \\
\hline 7 & 66.6 & 96.67 & 29 \\
\hline 8 & 100 & 90.00 & 44 \\
\hline 9 & 100 & 93.33 & 29 \\
\hline 10 & 100 & 90.00 & 32 \\
\hline 11 & 100 & 86.67 & 29
\end{tabular}




\begin{tabular}{cccc}
12 & 66.6 & 90.00 & 35 \\
\hline 13 & 100 & 73.33 & 28 \\
\hline 14 & 100 & 100.00 & 33 \\
\hline 15 & 100 & 83.33 & 36 \\
\hline 16 & 100 & 90.00 & 34 \\
\hline 17 & 100 & 93.33 & 29 \\
\hline 18 & 100 & 83.33 & 28 \\
\hline 19 & 100 & 90.00 & 36 \\
\hline 20 & 100 & 90.00 & 26 \\
\hline 21 & 100 & 96.67 & 25 \\
\hline 22 & 100 & 90.00 & 25 \\
\hline 23 & 100 & 93.33 & 35 \\
\hline 24 & 100 & 90.00 & 29 \\
\hline 25 & 100 & 83.33 & 28 \\
\hline 26 & 100 & 90.00 & 33 \\
\hline 27 & 66.6 & 73.33 & 39 \\
\hline 28 & 100 & 100.00 & 27 \\
\hline 29 & 66.6 & 83.33 & 32 \\
\hline 30 & 100 & 83.33 & 30 \\
\hline & 95,55 & 89,33 & 33 \\
\hline & &
\end{tabular}

Tabel 4 menunjukkan hasil efektivitas dari penggunaan media rotar yang dilakukan oleh ibu balita adalah tuntas, dengan skor ketepatan hasil 95,55\% dan respon angket 89,33\% (sangat positif), sedangkan oleh bidan adalah tuntas, dengan skor ketepatan hasil 97,77\% dan respon angket $92,67 \%$ (sangat positif). Untuk hasil efisiensi penggunaan media rotar oleh ibu balita dan BPM berturut-turut adalah 33 detik dan 27 detik.

Berdasarkan hasil analisis statistik pada siklus I yang telah dilakukan untuk menguji media roda putar lebih efektif dan efisien penggunaannya oleh bidan dalam menentukan status gizi balita dibandingkan dengan media buku. Pada tabel 2 didapat hasil analisis efektivitas penggunan media roda putar adalah tuntas dengan skor ketepatan 96,28 \% serta respon angket media roda putar sebesar 93,33\% (sangat positif), sedangkan efektivitas media buku adalah tuntas dengan skor ketepatan 85,17 $\%$ serta respon angket terhadap media buku sebesar $67,96 \%$ (kurang positif). Pada tabel 3, hasil analisis efisiensi penggunaan media roda putar didapatkan waktu penggunaan selama 33 detik, dengan waktu minimum 18 detik dan maksimum 69 detik, sedangkan efisiensi penggunaan media buku didapatkan waktu penggunaan selama 102 detik dengan waktu minimum 54 detik dan maksimum 199 detik.

Menurut Nieven (dalam Yuni Yamasari) media dikatakan efektivitas jika memenuhi indikator rata-rata skor hasil penggunaan media adalah tuntas, dengan hasil lebih besar atau sama dengan $80 \%$, serta adanya respon positif dari para responden yang ditunjukkan melalui angket terhadap pemakaian media roda putar.

Pada hasil analisis tabel 2 diperkuat oleh hasil penelitian M. Jaelani (2012) tentang peningkatan kemampuan menulis huruf Al Quran melalui pengunaan media roda putar pada siswa kelas III SD Negeri 2 Pegulon Kendal, yang menunjukkan adanya peningkatan hasil belajar setelah menggunakan media pembelajaran rotar. Perubahan yang diperoleh yaitu meningkatnya nilai ketuntasan belajar siswa, dari siklus awal $\begin{array}{lll}\text { mencapai } & \text { ketuntasan } & 24\end{array}$ 
dengan nilai rata-rata 54,5. Pada siklus I ketuntasannya mencapai $32 \%$ dengan nilai ratarata 63,0, sedangkan pada siklus II ketuntasannya mencapai $76 \%$ dengan nilai ratarata 72,8 . Hal ini menunjukkan bahwa dengan menggunakan media rotar, terjadi peningkatan yang signifikan pada hasil belajar siswa dalam kemampuan menulis huruf $\mathrm{Al}$ Qur'an. ${ }^{24}$

Pada penelitian lainnya yang dilakukan oleh Desy Ramdhanasari (2013), dengan judul efektivitas penggunaan media tajwid putar terhadap hasil belajar dalam pembelajaan PAI disimpulkan bahwa dengan menggunakan media tajwid putar terdapat perbedaan yang signifikan pada kemampuan pemahaman hukum bacaan nun mati/Tanwin dan mim mati antara siswa yang melakukan pembelajaran dengan media tajwid putar dengan yang tidak menggunakan media tajwid putar. ${ }^{20}$

Penelitian yang dilakukan oleh Hilaluddin Hanafi (2014) tentang strategi meningkatkan kemampuan berbahasa anak melalui permainan papan putar bergambar pada anak kelompok B di TK Negeri Pembina Kendari. Hasil evaluasi dalam siklus I menunjukkan tingkat pencapaian $60 \%$. Tahap ini belumlah mencapai hasil yang baik, karena faktor anak yang masih belum maksimal dalam melaksanakan kegiatan penelitian. Pada siklus II telah mencapai 90\%, ditandai dengan kemampuan berbahasa anak melalui kegiatan bermain papan putar bergambar menunjukkan hasil yang lebih baik. ${ }^{19}$

R. Usman Rery dalam penelitiannya yang berjudul penggunaan alat roda-roda pelangi untuk meningkatkan prestasi belajar siswa pada pokok bahasan ikatan kimia menunjukkan bahwa penggunaan alat peraga roda-roda pelangi dapat meningkatkan hasil belajar siswa secara signifikan $(21,48 \%)$. Peningkatan ini ditenggarai karena pada pembelajaran dengan menggunakan alat peraga ini siswa terlibat secara aktif, siswa ditantang dalam kompetisi, siswa dapat bekerja sama di dalam kelompok. ${ }^{18}$

Pada pembahasan efisiensi menurut KBBI adalah ketepatan cara dalam menjalankan sesuatu dengan tidak membuang-buang waktu, tenaga dan biaya. Dalam penelitian ini yang akan dibahas hanya pada penilaian waktu pemakaian media roda putar dan media buku. Peneliti menghitung waktu penggunaan media roda putar dan media buku terhadap penilaian status gizi balita dalam bentuk satuan detik yang dijadikan dua kategori, yaitu cepat $(\leq$ median) dan lama (> median). Pada tabel 4.3 hasil analisis data efisiensi waktu penggunaan media roda putar lebih baik dibanding media buku dalam menilai status gizi balita. Asumsi peneliti, media roda putar tersebut lebih baik efisiensinya dibanding media buku dikarenakan pada pemakaian media roda putar dalam satu kali putaran, langsung mendapatkan diagnosa status gizi balita dengan tiga indikator sekaligus, sedangkan pada media buku untuk mendapatkan diagnosa status gizi balita harus mengerjakan 3 tahap dalam mendapatkan tiga indikator status gizi balita dan harus membulakbalikan tiap lembar media buku untuk mencocokan diagnosa status gizi balita dengan hasil indikator yang didapat. Hal ini tentunya dapat terlihat betapa singkatnya pemakaian media roda putar dibanding media buku dalam menilai status gizi balita.

Pada siklus II, menguji penggunaan media roda putar efektif dan efisien terhadap penilaian status gizi balita. Pada tabel 4 didapat hasil analisis efektivitas yaitu seluruh ibu balita dan bidan tuntas dalam menilai status gizi balita dengan menggunakan media roda putar, skor penggunaan media roda putar terhadap ketepatan hasil penilaian status gizi balita oleh ibu balita sebesar $95,55 \%$ dan $97,77 \%$ oleh bidan praktik mandiri, serta skor tanggapan responden terhadap media roda putar (respon melalui angket) sebesar $89,33 \%$ oleh ibu balita dan sebesar $92,67 \%$ oleh bidan. Untuk hasil analisis data efisiensi penggunaan media roda putar terhadap penilaian status gizi balita oleh ibu balita dengan rata-rata waktu 33 detik, sedangkan pada bidan dengan rata-rata waktu 27 detik. Berdasarkan hasil diatas dapat disimpulkan bahwa penggunaan media roda putar terbukti efektif dan efisien dalam menilai status gizi balita. 


\section{SIMPULAN}

Berdasarkan hasil penelitian dan pembahasan, simpulan yang dapat diambil dari penelitian ini adalah:

1) Penggunaan media roda putar status gizi balita lebih efektif dan efisien dibandingkan dengan media buku dalam menilai status gizi balita.

2) Penggunaan media roda putar status efektif dan efisien terhadap penilaian status gizi balita.

\section{REFERENSI}

Balitbangkes, Kemenkes. (2013). Riskesdas Menkokesra RI. (2013) Pedoman Perencanaan Program Gerakan Nasional Percepatan Perbaikan Gizi Dalam Rangka Hari Pertama Kehidupan (Gerakan 1000 HPK).

Kepmenkes RI. (2010). Standar Antropometri Penilaian Status Gizi Balita Nomor:1995/Menkes/SK/XII/2010.

Kepmenkes RI. (2010). Penggunaan Kartu Menuju Sehat (KMS) bagi balita No.155/Menkes/Per/I/2010.

Murti FH, Riyanto DE, Suhartono. Aplikasi Berbasis Web Untuk Pemantauan Status Gizi dan Tumbuh Kembang Anak Berdasarkan Data Antropometri.

Menkokesra RI. (2013). Kerangka Kebijakan Gerakan Nasional Percepatan Perbaikan Gizi Dalam Rangka Seribu Hari Pertama Kehidupan (1000 HPK).

Supariasa. (2000). Penilaian Status Gizi Balita: Buku Kedokteran EGC.

Supariasa DN, Bakri B, Fajar I. (2000). Penilaian Status Gizi Balita: Buku Kedokteran EGC.

Soekirman. (2000). Ilmu Gizi Dan Aplikasinya Untuk Petugas Dan Masyarakat: Direktorat Jenderal Pendidikan Tinggi

Almatsier S. (2004). Prinsip Dasar Ilmu Gizi: Gramedia.

Depkes RI. (2010). Pedoman Pelaksanaan Stimulasi Deteksi Dini Tumbuh Kembang
Anak Di Tingkat Pelayanan Kesehatan Dasar: Bakti Husada.

Adriani M. (2014). Gizi Dan Kesehatan Balita: Kencana Prenada Media Grup.

Eveline, Djamaludin N. (2010). Panduan Pintar Merawat Bayi Dan Balita: PtT. Wahyu Medika.

Arsyad. (2011). Media Pembelajaran: PT. Raja Grafindo Persada.

Rerry U. Penggunaan Alat Roda-roda Pelangi Untuk Meningkatkan Prestasi Belajar Siswa Pada Pokok Bahasan Ikatan Kimia: Universitas Riau.

Hanafi H. (2014). Strategi Meningkatkan Kemampuan Berbahasa Anak Melalui Permainanan Papan Catur Bergambar pada Anak Kelompok B di TK Negeri Pembina Kenduri. Jurnal Pendidikan Bahasa.

Ramdhanasari D. (2013). Efektivitas Penggunaan Media Tajwid Putar Terhadap Hasil Belajar Dalam Pembelajaran PAI: Universitas Pendidikan Indonesia.

Mangkunegara AP. (2009). Manajemen Sumber Daya Manusia. Bandung: PT. Remaja Rosda Karya.

Jaelani M. (2012). Peningkatan Kemampuan Menulis Huruf Al Qur'an Melalui Penggunaan Rotar Siswa Kelas III SD Negeri Pegulon Kendal.

Dahlan S. (2010). Besar Sampel Dan Cara Pengambilan Sampel Dalam Penelitian Kedokteran Dan Kesehatan: Salemba Medika.

Notoatmodjo S. (2012). Metodologi Penelitian Kesehatan: Rineka Cipta.

Mubarak WI. (2011). Promosi Kesehatan Untuk Kebidanan Jakarta. Salemba Medika.

Halim R. (2013). Faktor-faktor yang berhubungan dengan kinerja bidan desa dalam kegiatan pelayanan antenatal di kabupaten batang hari populasi Jambi. 